\author{
V.I. HUTSULIAK ${ }^{1}$, R.D.BORODAJKEVYCH ${ }^{2}$, A.I. HUTSULIAK ${ }^{1}$,
} T.M.KOVALYSHYN ${ }^{1}$

\title{
DEVELOPMENT AND APPLICATION FEATURES OF 3-D ATLAS OF TRANSOSSEOUS ELEMENTS POSITIONS FOR PRE-SURGERY PLANNING OF THE SHIN BONES OSTEOSYNTHESIS
}

\author{
Ivano-Frankivsk National Medical University ${ }^{1}$, Ivano-Frankivsk, \\ Specialized (special) sanatorium «Girskepovitria» ${ }^{2}$, Yaremche,
}

Ukraine

Цель. Оптимизировать процесс предоперационного планирования чрескостного остеосинтеза при переломах костей голени путем разработки и применения 3-D атласа позиций чрескостных элементов.

Материал и методы. На основе поперечных компьютерных томографических сканов интактной нижней конечности взрослого человека, с помощью программного пакета 3-D Doctor в автоматическом режиме, созданы трехмерные имитационные модели костей голени и окружающих их мягкотканных структур. Данные модели экспортированы в программный комплекс Autodesk Inventor 11. В режиме Part Modeling проведено разделение модели мягкотканных структур голени на 96 частей - сегментов, соответствующих позициям для проведения чрескостных элементов согласно методу унифицированного обозначения чрескостного остеосинтеза, и их сохранение в отдельных файлах. В режиме «Assembly» программы проведена сборка сегментов голени.

Результаты. Предложен алгоритм действий для создания 3-D атласа позиций для проведения чрескостных элементов, согласно которому в программе Autodesk Inventor 11 созданы трехмерные имитационные модели систем «голень - аппарат внешней фиксации» и проведен анализ их возможностей по предоперационному планированию чрескостного остеосинтеза.

В результате проведенного исследования установлено, что использование 3-D атласа позиций обеспечивает возможность выбора оптимальной конструкции и наиболее рациональной, в каждой конкретной клинической ситуации, компоновки аппарата внешней фиксации; определения количества и оптимальных уровней расположения опор; выбора типа и наиболее целесообразных мест проведения чрескостных элементов.

Заключение. Применение 3-D атласа позиций чрескостных элементов позволяет вплотную приблизиться к решению вопроса предоперационного планирования с позиций комплексного подхода: адекватного существующей клинической ситуации выбора типа аппарата внешней фиксации, его компоновки, определения количества чрескостных элементов, направлений и плоскостей их проведения, что позволит значительно уменьшить количество технических ошибок, обеспечит снижение рисков возникновения осложнений и будет способствовать достижению положительных анатомо-функциональных результатов в подавляющем большинстве клинических случаев.

Ключевые слова: трехмерная модель, аппарат внешней фиксации, чрескостный остеосинтез, чрескостные элементы, предоперационное планирование

Objective. To improve the pre-surgery planning of transosseous osteosynthesis in the shin bone fractures by developing and applying the 3-D atlas of transosseous elements positions.

Methods. On the basis of transverse computer tomographic scans of the intact lower limb of an adult using the 3-D Doctor software package, three-dimensional simulation models of the shin bones and surrounding soft tissue structures were created in the automatic mode. These models were exported as separate files into the Autodesk Inventor 11 software package. In Part Modeling mode, the division of the model of the soft tissue structures of the shin into 96 parts was carried out - the segments corresponding to the positions for passing the transosseous elements according to the method of the unified marking of transosseous osteosynthesis and their preservation in separate files. In Assembly mode, the assemblage of the shin segments has been performed.

Results. The algorithm for the creation of 3-D atlas of transosseous elements positions was proposed, according to which the three-dimensional simulation models of the «shin - external fixation device» system were created in the Autodesk Inventor 11 program and the analysis of their possibilities regarding pre-surgery planning of transosseous osteosynthesis was conducted.

As a result of the research, it was found out that the use of the 3-D atlas of positions provides an opportunity for selecting the optimal design and the most efficient layout of the external fixation device in each particular clinical situation; determination of the number and optimal layout levels of the supports; the choice of the type and the most appropriate places for passing of the transosseous elements.

Conclusions. The application of 3-D Atlas of transosseous elements positions permits to approach the 
solution of the problem of pre-surgery planning from the standpoint of an integrated approach to choosing the type of external fixation device that is adequate to the existing clinical situation, its layout, determining the number of transosseous elements, directions and planes for passing them, which will allow reducing significantly the number of technical errors, reducing the risk of complications and promoting the achievement of positive anatomical and functional results in the vast majority of clinical cases.

Keywords: three-dimensional model, external fixation device, transosseous osteosynthesis, transosseous elements, pre-surgery planning

Novosti Khirurgii. 2019 Jul-Aug; Vol 27 (4): 428-434

Development and Application Features of 3-D Atlas of Transosseous

Elements Positions for Pre-surgery Planning of the Shin Bones Osteosynthesis

V.I. Hutsuliak, R.D. Borodajkevych, A.I. Hutsuliak, T.M. Kovalyshyn

The articles published under CC BY NC-ND license

\section{Научная новизна статьи}

Впервые разработан 3-D атлас позиций чрескостных элементов для остеосинтеза костей голени и проведен анализ его возможностей относительно предоперационного планирования чрескостного остеосинтеза. Установлено, что применение предложенного 3-D атласа обеспечивает возможность выбора адекватного существующей клинической ситуации типа конструкции и компоновки аппарата внешней фиксации, установления оптимальных уровней расположения опор, определения типа и наиболее рациональных позиций для чрескостных элементов, что позволяет значительно повысить эффективность планирования чрескостного остеосинтеза.

\section{What this paper adds}

For the first time, 3-D Atlas of transosseous elements positions for osteosynthesis of the shin bones has been developed and the analysis of its capabilities regarding pre-surgery planning of transosseous osteosynthesis has been made. It has been established that the application of the proposed 3-D atlas allows the choice of an appropriate type of design of the external fixation device, the establishment of optimal levels for supports, the determination of the most rational positions for transosseous elements, which allows improving significantly the efficiency of the planning of transosseous osteosynthesis.

\section{Introduction}

To achieve positive anatomical and functional results of treating patients with fractures and deformities of limb bones using transosseous osteosynthesis (TOO), careful preoperative planning plays an important role $[1,2,3]$, one of the tasks of which is to determine the most significant transosseous elements (TOE) for a particular clinical situation and positions for their implementation [4].This requires, in addition to perfect knowledge of the limb topographic anatomy, taking into account the type of fracture, the location of bone fragments and the state of the soft tissue structures of the segment. All this creates certain difficulties for carrying out rapid preoperative planning of TOO. To simplify this task, the atlases of positions for conducting TOE are used $[4,5,6]$, including two-dimensional sketches of horizontal "sections" of limb segments. However, they do not provide a full visual perception of the spatial location of the bone and soft tissue anatomical structures of the limb, which is an obstacle to the selection of optimal positions for conducting TOE.

One of the modern practices of preoperative planning is the method of computer threedimensional modeling $[7,8,9]$. The use of special software allows performing simulation computer design of various layouts of external fixation devices (DEF) and models of the bone-fixer system [10, 11]. However, currently known three-dimensional models of biomechanical systems for TOOdo not provide visualization of the topographic and anatomical features of the segments, which is extremely necessary to determine the most rational locations of TOE and layout of DEF.

Therefore, the development of a 3-D atlas of positions for transosseous elements remains an unresolved and relevant issue of modern traumatology and orthopedics.

Objective. To improve the pre-surgery planning of transosseous osteosynthesis in the shin bone fractures by developing and applying the 3-D atlas of transosseous elements positions.

\section{Methods}

To work out a 3-D atlas of positions of transosseous elements, transverse spiral computed tomographic scans of an intact adult lower limb were used, of which three-dimensional imitation models of the lower leg bones and soft tissue structures surrounding them were automatically created using the 3-D Doctor software package. These models as separate files are exported to the Autodesk Inventor 11 software package.

In Part Modeling mode, the model of softtissue shin structures was divided into 96 parts segments corresponding to positions for performing TOO according to the unified designation of transosseous osteosynthesis $[4,6]$, and their storage in separate files. The shin segments were assembled in Assembly mode. Its essence was to load previously 
created segments into the model file and place them in "their" places by establishing dependencies using the "Place Constraint" command. The mechanism of dependency determination provided for the possibility of fixing the part in the assembly in the required position.

Parts of devices were developed in the Autodesk Inventor 11 software package in Part Modeling mode using various modeling methods [12]. In particular, the template method was applied, the principle of construction of which is to model new parts by making the necessary changes to the parameters of previously created parts that serve as templates.

In the Assembly mode of the program, a threedimensional simulation model of the "shin - DEF" system was created and the analysis of its capabilities for preoperative planning of TOO was performed.

\section{Results}

For the construction of the 3-D Atlas of transosseus elements positions for osteosynthesis of shin bones, an action algorithm has been developed that includes the following steps:

- creation of models of bones and soft tissues (ST) of the shin and saving them in separate Part Modeling files; installation of compatible points or axes (not less than two) for models of bones and soft tissue structures;

- installation of compatible points or axes (not less than two) for models of bones and soft tissue structures;

- creating an assembly file «Assembly» and inserting into it shin bones and ST with matching of pre-installed, adjacent points or axes;

- determination of the part of the shins ST that corresponds to the levels of the location of the meta parts and diaphyseal parts of the tibia (Figure 1A) and its preservation in a separate file;
- the division of this part of the shin with 7 equidistant horizontal sections into 8 segments (Fig. 1 b);

- division of each of the segments into 12 sectors with a center located on the longitudinal axis of the tibia (Fig. 2);

- creation of separate files for each sector;

- insertion of the sectors into their location in the assembly file (Fig. 3);

- designation of sectors corresponding to the recommended positions - green, accessibility positions - yellow, and prohibited - red (fig. 3);

- creation of opposite shin model in the assembly file by creating a mirror copy using the Mirror command (Figure 4).

On the basis of the created 3-D atlas of transosseus elements positions a simulation of TOO in case of fractures of the shin bones was performed using the Ilizarov device and the developed device of Hutsuliak for correction of deformations of bones and joints (patent for invention No. 87072, Ukraine, IPC ABB 17/56).For this purpose, in the assembly file, the tibia model is replaced by models of its proximal and distal fragments, with six cross-cutting holes at each of the eight levels passing through the center of the medullar channel. In each of the holes "working" axis are installed (Fig. 5).

Transosseus elements, located in the defined holes of the tibia, were passed by establishing dependencies with the "working" axes using the "Place Constraint" command.

The next step was to insert details and layout of the DEF frames, in particular, three-dimensional simulation models of the "shin- device of Ilizarov" (Fig. 6A) and "shin -device of Hutsuliakfor correction of bone and joint deformation" were created (Fig. 6B).

As a result of the research, it has been found that the use of the 3-D Atlas of transosseus elements positions provides an opportunity for:

Fig. 1. General view of the three-dimensional model of the shin at stages of construction of the 3-D atlas: A - model of the shin without a part of the soft tissue structures at the level of placement of meta- and diaphyseal parts of the tibia; B - division of shins ST into 8 segments.

A

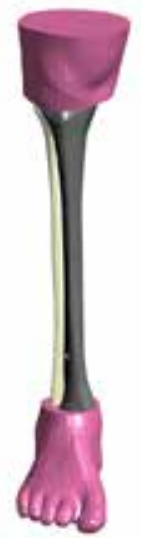

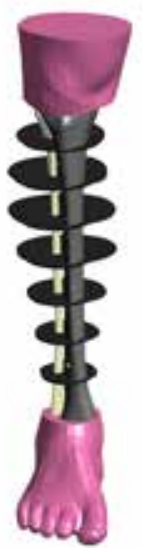

B

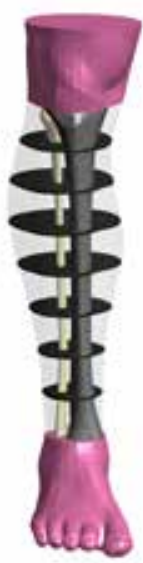



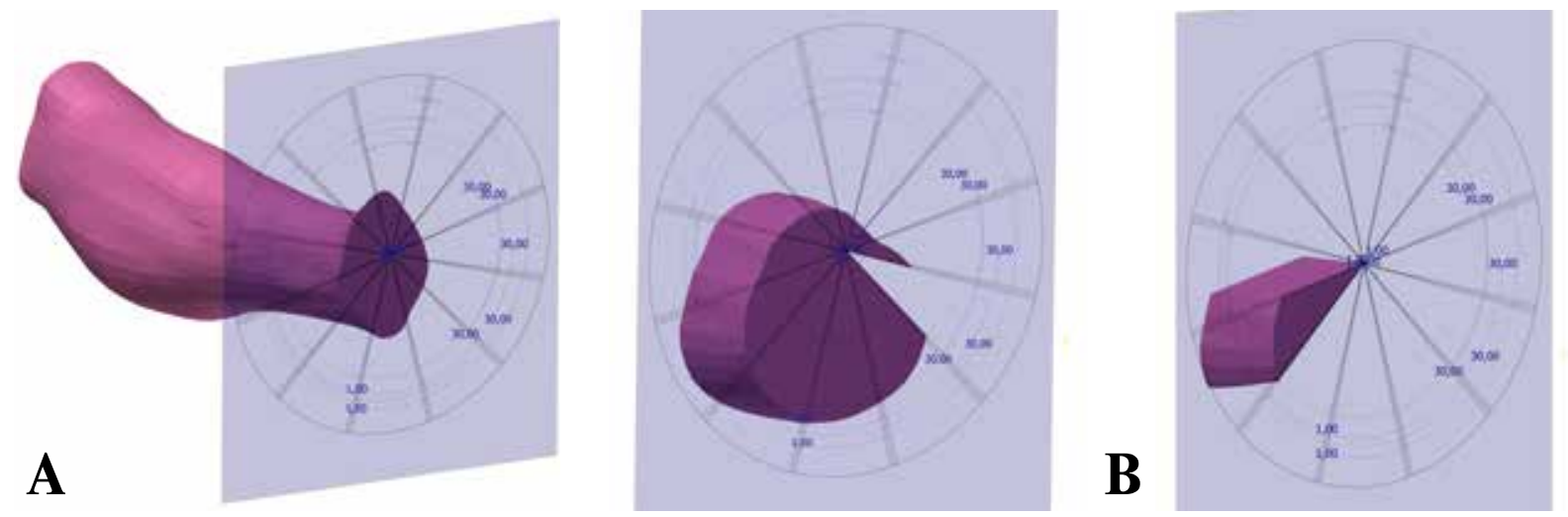

Fig. 2. The general view of the three-dimensional model of the soft tissue structures of the shin at the stage of division of the segments into 12 sectors: A - creating a sketch on the «working» plane for the division of the shin segments into 12 sectors; $B$ - division of the segment of the shin into sectors.

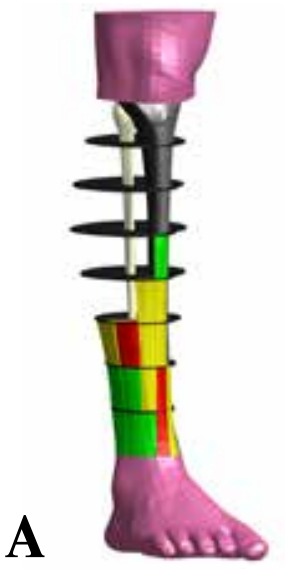

Fig. 3. General view of the three-dimensional model of the shin at the final stages of simulation: $A$ - at the stage of inserting sectors into their location in the assembly file; $B$ - general view of the 3-D model of transosseus elements positions for the right shin, the view from the lateral side.
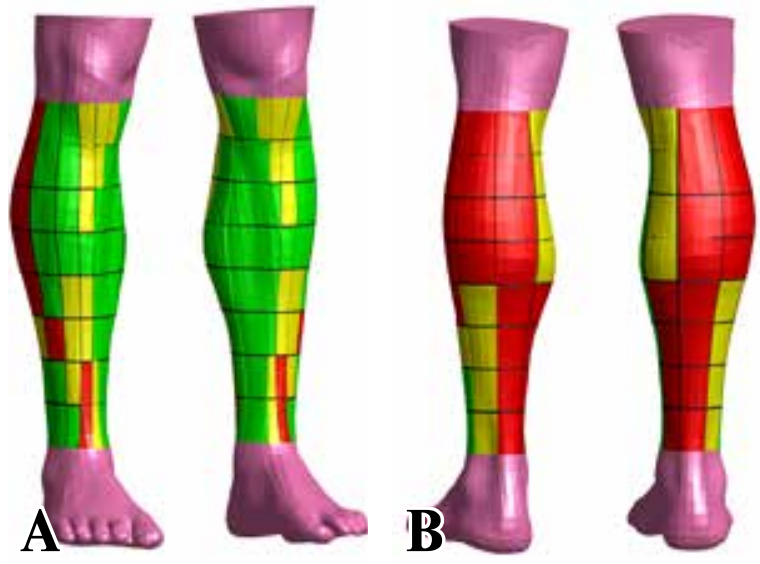

Fig. 4. General view of model 3-D atlas of transosseus elements positions of both shins: $A$ - the front view; B - rear view.
A

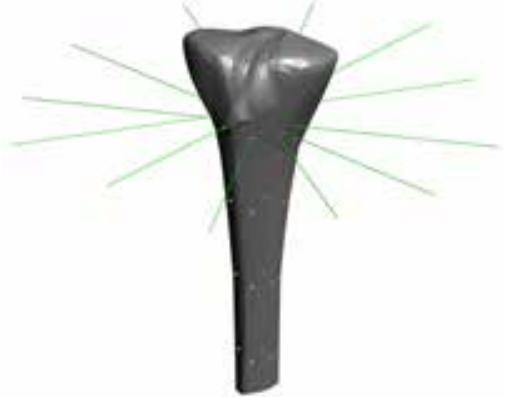

B

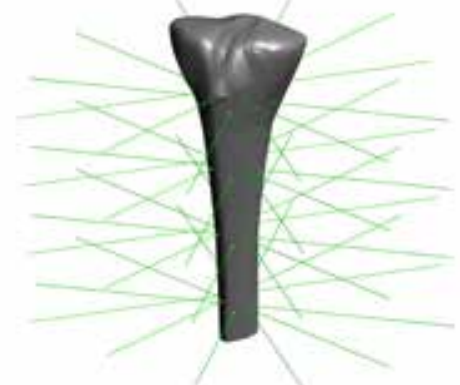

Fig. 5. General view of three-dimensional model of proximal fragment of tibia: A - with six «working» axes installed in holes in the first level; B - with installed «working» axes on four levels.

- choice of optimal design of DEF;

- determination of the most rational, in each concrete clinical situation, layout of the DEF;

- determination of the number and optimal layout levels of the supports;

- choice of type and the most rational sites and planes for passing the TOE.

\section{Discussion}

In connection with the rapid development of 3 -D visualization computer technologies over the past decades, the scientific search of many authors is aimed at using three-dimensional modeling for surgical interventions $[7,8,9,10]$ 

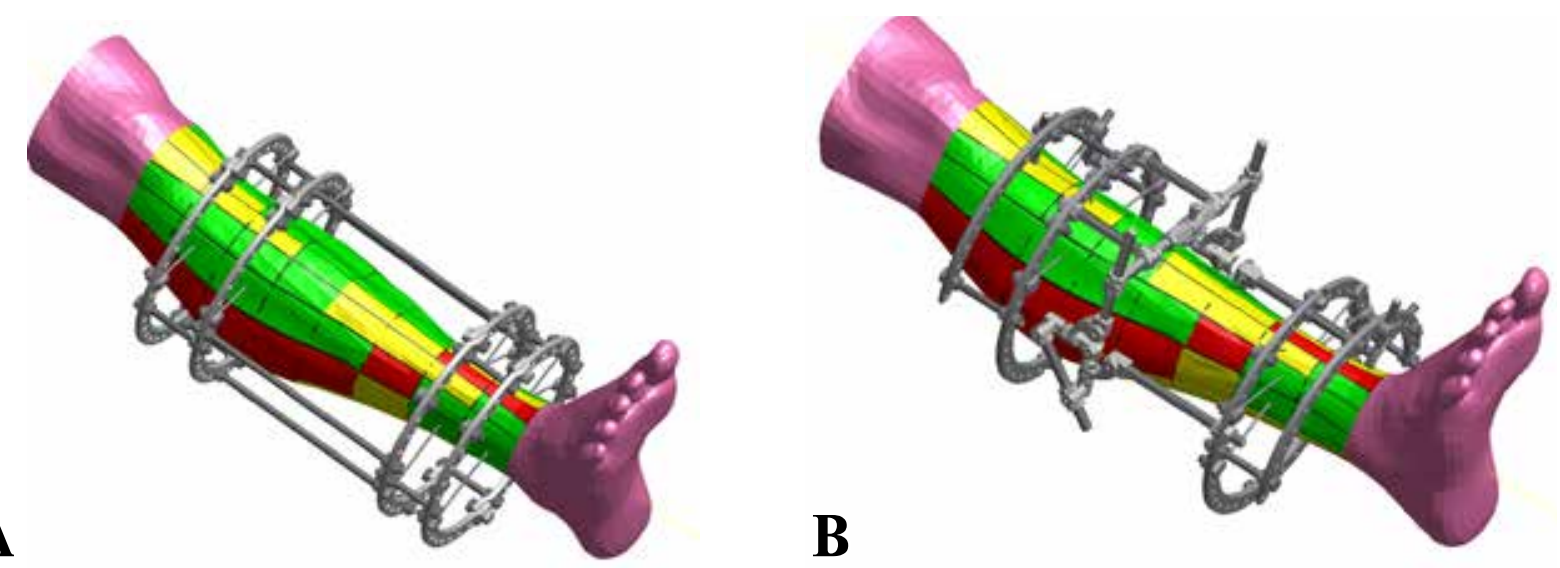

Fig. 6. General view of three-dimensional models of biomechanical systems: A - «shin - device of Ilizarov», an axonometric projection; B - «shin - device for correction of deformations of bones and joints», an axonometric projection.

The obtained results confirm the feasibility of using three-dimensional computer modeling for preoperative planning of TOO, which corresponds to modern trends in the development of traumatology and orthopedics [13].

An algorithm of actions is proposed for creating a 3-D atlas of positions of transosseous elements, on the basis of which it is possible to create threedimensional models of various biomechanical systems "shin - DEF". A distinctive feature of these models is the actual visualization of the topographic and anatomical features of the segments, which undoubtedly simplifies, in comparison with the known analogues $[8,14]$, the process of choosing the most rational locations of TOE and layout of DEF.

Based on the foregoing, the developed 3-D atlas can be recommended for use in clinical practice, in particular for preoperative planning of TOO of the leg bones.

\section{Conclusions}

The application of the 3-D Atlas of transosseus elements positions allows approaching the solution of the problem of pre-surgery planning from the standpoint of an integrated approach to choosing the type of DEF that is adequate to the existing clinical situation, its layout, determining the number of transosseus elements, directions and planes for passing them, which will allow significantly to reduce the number of technical errors, to reduce the risk of complications and to promote the achievement of positive anatomical and functional results in the vast majority of clinical cases.

\section{Funding}

The work was carried out in accordance with the plan of scientific works of Ivano-Frankivsk National Medical University.

\section{Conflict of interest}

The authors declare that they have no conflict of interest.

\section{Ethicalaspects}

The work was approved by the Committee on the Ethics of Ivano-Frankivsk National Medical University.

\section{ЛИТЕРАТУРА}

1. Hughes A, Parry M, Heidari N, Jackson M, Atkins R, Monsell F. Computer Hexapod-Assisted Orthopaedic Surgery for the Correction of Tibial Deformities. J Orthop Trauma. 2016 Jul;30(7):e256-61. doi: 10.1097/BOT.0000000000000544

2. Murase T, Oka K, Moritomo H, Goto A, Sugamoto $\mathrm{K}$, Yoshikawa H. Correction of severe wrist deformity following physeal arrest of the distal radius with the aid of a three-dimensional computer simulation. Arch Orthop Trauma Surg. 2009;129:1465-71. doi 10.1007/ s00402-008-0800-x

3. Rozbruch SR, Fragomen AT, Ilizarov S. Correction of tibial deformity with use of the Ilizarov-Taylor spatial frame. J Bone Joint Surg Am. 2006 Dec;88(Suppl 4):156-74. doi: 10.2106/JBJS.F.00745

4. Соломин ЛН. Основы чрескостного остеосинтеза аппаратом Г.А. Илизарова. С-Петербург, РФ; 2005.

$544 \mathrm{c}$. http://www.medliter.ru/?page=get\&id=015127

5. Catagni MA. Atlas for the insertion of transosseous wires and half-pins. Ilizarov method. 2nd ed. Milan: Medicalplastic; 2003. 51 p. Available from: http://osteosyntese.dk/3033/Smith-Nephew-Pinatlas.pdf

6. Solomin L. The basic principles of external skeletal fixation using the Ilizarov and other devices. 2nd ed. Milan: Springer-Verlag; 2012. 1593 p. https://www. springer.com/us/book/9788847026186

7. Okada T, Iwasaki Y, Koyama T, Sugano N, Chen YW, Yonenobu K, Sato Y. Computer-assisted preoperative planning for reduction of proximal femoral fracture using 3-D-CT data. IEEE Trans Biomed Eng. 2009 Mar;56(3):749-59. doi: 10.1109/ TBME.2008.2005970 
8. Fürnstahl P, Székely G, Gerber C, Hodler J, Snedeker JG, Harders M. Computer assisted reconstruction of complex proximal humerus fractures for preoperative planning. Med Image Anal. 2012 Apr;16(3):704-20. doi: 10.1016/j.media.2010.07.012

9. Buschbaum J, Fremd R, Pohlemann T, Kristen A. Computer-assisted fracture reduction: a new approach for repositioning femoral fractures and planning reduction paths. Int J Comput Assist Radiol Surg. 2015 Feb;10(2):149-59. doi: 10.1007/s11548014-1011-2

10. Qiao F, Li D, Jin Z, Hao D, Liao Y, Gong S. A novel combination of computer-assisted reduction technique and three dimensional printed patient-specific external fixator for treatment of tibial fractures. Int Orthop. 2016 Apr;40(4):835-41. doi: 10.1007/s00264015-2943-z

11. Wei M, Chen J, Guo Y, Sun H. The computeraided parallel external fixator for complex lower limb deformity correction. Int J Comput Assist Radiol Surg. 2017 Dec;12(12):2107-17. doi: 10.1007/s11548-0171654-X

12. Концевич ВГ. Твердотельное моделирование в Autodesk Inventor. Киев, Москва: Диа-СофтЮП: ДМК Пресс; 2008. 672 с. http://www.okindiansbc. org/articles/60337-koncevich-v.-tverdotelnoemodelirovanie.html

13. Jiménez-Delgado JJ, Paulano-Godino F, PulidoRam-Ramírez R, Jiménez-Pérez JR. Computer assisted preoperative planning of bone fracture reduction: Simulation techniques and new trends. Med Image Anal. 2016 May;30:30-45. doi: 10.1016/j.media.2015.12.005 14. Willis A, Anderson DD, Thomas T, Brown T, Marsh JL. 3D reconstruction of highly fragmented bone fractures. Medical Imaging. 2007: Image Processing: art. 65121P. doi:10.1117/12.708683

\section{REFERENCES}

1. Hughes A, Parry M, Heidari N, Jackson M, Atkins R, Monsell F. Computer Hexapod-Assisted Orthopaedic Surgery for the Correction of Tibial Deformities. J Orthop Trauma. 2016 Jul;30(7):e256-61. doi: 10.1097/BOT.0000000000000544

2. Murase T, Oka K, Moritomo H, Goto A, Sugamoto $\mathrm{K}$, Yoshikawa H. Correction of severe wrist deformity following physeal arrest of the distal radius with the aid of a three-dimensional computer simulation. Arch Orthop Trauma Surg. 2009;129:1465-71. doi 10.1007/ s00402-008-0800-X

3. Rozbruch SR, Fragomen AT, Ilizarov S. Correction of tibial deformity with use of the Ilizarov-Taylor spatial frame. J Bone Joint Surg Am. 2006 Dec;88(Suppl 4):156-74. doi: 10.2106/JBJS.F.00745

\section{Адрес для корреспонденции}

76000, Украина,

Ивано-Франковская обл.,

г. Ивано-Франковск, ул. Галицкая, 2,

Ивано-Франковский национальный медицинский университет,

кафедра травматологии и ортопедии,

тел. моб.: +38050-960-59-23,

e-mail: vitaliy.ivf@ukr.net,

Гуцуляк Виталий Иванович
4. Solomin LN. Osnovy chreskostnogo osteosinteza apparatom GA. Ilizarova. S-Petersburg, RF; 2005. 544 p. http://www.medliter.ru/?page $=$ get\&id $=015127$ (In Russ.)

5. Catagni MA. Atlas for the insertion of transosseous wires and half-pins. Ilizarov method. 2nd ed. Milan: Medicalplastic; 2003. 51 p. Available from: http:// osteosyntese.dk/3033/Smith-Nephew-Pin-atlas.pdf

6. Solomin L. The basic principles of external skeletal fixation using the Ilizarov and other devices. 2nd ed. Milan: Springer-Verlag; 2012. 1593 p. https://www. springer.com/us/book/9788847026186

7. Okada T, Iwasaki Y, Koyama T, Sugano N, Chen YW, Yonenobu K, Sato Y. Computer-assisted preoperative planning for reduction of proximal femoral fracture using 3-D-CT data. IEEE Trans Biomed Eng. 2009 Mar;56(3):749-59. doi: 10.1109/ TBME.2008.2005970

8. Fürnstahl P, Székely G, Gerber C, Hodler J, Snedeker JG, Harders M. Computer assisted reconstruction of complex proximal humerus fractures for preoperative planning. Med Image Anal. 2012 Apr;16(3):704-20. doi: 10.1016/j.media.2010.07.012 9. Buschbaum J, Fremd R, Pohlemann T, Kristen A. Computer-assisted fracture reduction: a new approach for repositioning femoral fractures and planning reduction paths. Int J Comput Assist Radiol Surg. 2015 Feb;10(2):149-59. doi: 10.1007/s11548014-1011-2

10. Qiao F, Li D, Jin Z, Hao D, Liao Y, Gong S. A novel combination of computer-assisted reduction technique and three dimensional printed patient-specific external fixator for treatment of tibial fractures. Int Orthop. 2016 Apr;40(4):835-41. doi: 10.1007/s00264015-2943-z

11. Wei M, Chen J, Guo Y, Sun H. The computeraided parallel external fixator for complex lower limb deformity correction. Int J Comput Assist Radiol Surg. 2017 Dec;12(12):2107-17. doi: 10.1007/s11548-0171654-X

12. Kontsevich VG. Tverdotel'noe modelirovanie v Autodesk Inventor. Kiev, Moscow: Dia-SoftIuP: DMK Press; 2008. 672 p. http://www.okindiansbc. org/articles/60337-koncevich-v.-tverdotelnoemodelirovanie.html (In Russ.)

13. Jiménez-Delgado JJ, Paulano-Godino F, PulidoRam-Ramírez R, Jiménez-Pérez JR. Computer assisted preoperative planning of bone fracture reduction: Simulation techniques and new trends. Med Image Anal. 2016 May;30:30-45. doi: 10.1016/j.media.2015.12.005 14. Willis A, Anderson DD, Thomas T, Brown T, Marsh JL. 3D reconstruction of highly fragmented bone fractures. Medical Imaging. 2007: Image Processing: art. 65121P. doi: $10.1117 / 12.708683$

\section{Address for correspondence}

76000, Ukraine,

Ivano-Frankivsk, Galitskaya Str., 2,

Ivano-Frankivsk National Medical University,

Department of Traumatology and Orthopedics.

Tel. mobile+38050-960-59-23,

e-mail: vitaliy.ivf@ukr.net,

Vitalii I.Hutsuliak 
Сведения об авторах

Гуцуляк Виталий Иванович, к.м.н., доцент, кафедра травматологии и ортопедии, Ивано-Франковский национальный медицинский университет, г. ИваноФранковск, Украина.

https://orcid.org/0000-0003-1041-6424

Бородайкевич Роман Дмитриевич, к.м.н., главный врач, специализированный (специальный) санаторий «Горный воздух» МЗ Украины, г. Яремче, Украина.

https://orcid.org/0000-0003-2841-7572

Гуцуляк Андрей Иванович, д.м.н., доцент, кафедра хирургии № 1, Ивано-Франковский национальный медицинский университет, г. Ивано-Франковск, Украина.

https://orcid.org/0000-0002-3665-7798

Ковалишин Тарас Михайлович, к.м.н., доцент кафедры травматологии и ортопедии, Ивано-Франковский национальный медицинский университет, г. Ивано-Франковск, Украина.

https://orcid.org/0000-0003-2388-1149

\section{Информация о статье}

Получена 6 января 2019 г.

Принята в печать 17 июня 2019 г.

Доступна на сайте 1 сентября 2019 г.

\section{Information about the authors}

Hutsuliak Vitalii I., PhD, Associate Professor of the Department of Traumatology and Orthopedics, Ivano-Frankivsk National Medical University, IvanoFrankivsk, Ukraine.

https://orcid.org/0000-0003-1041-6424

Borodajkevych Roman D., PhD, Chief Physician of the Specialized (Special) Sanatorium «Girske Povitria», Yaremche, Ukraine.

https://orcid.org/0000-0003-2841-7572

Hutsuliak AndriiI., MD, Associate Professorofthe Surgery Department № 1, Ivano-Frankivsk National Medical University, Ivano-Frankivsk, Ukraine.

https://orcid.org/0000-0002-3665-7798

Kovalyshyn Taras M., PhD, Associate Professor of the Department of Traumatology and Orthopedics, Ivano-Frankivsk National Medical University, IvanoFrankivsk, Ukraine.

https://orcid.org/0000-0003-2388-1149

\section{Article history}

Arrived: 6 January 2019

Accepted for publication: 17 June 2019

Available online: 1 September 2019 